University of Nebraska - Lincoln

DigitalCommons@University of Nebraska - Lincoln

Faculty Publications from the Harold W. Manter Laboratory of Parasitology

6-1990

\title{
Three New Coccidia (Apicomplexa) from the Hood Island Lizard, Tropidurus delanonis, from the Galápagos Archipelago
}

Aida Luz Aquino-Shuster

Ciudad Uni- versitaria, San Lorenzo

Donald W. Duszynski

University of New Mexico, eimeria@unm.edu

Howard L. Snell

University of New Mexico

Follow this and additional works at: https://digitalcommons.unl.edu/parasitologyfacpubs

Part of the Parasitology Commons

Aquino-Shuster, Aida Luz; Duszynski, Donald W.; and Snell, Howard L., "Three New Coccidia (Apicomplexa) from the Hood Island Lizard, Tropidurus delanonis, from the Galápagos Archipelago" (1990). Faculty Publications from the Harold W. Manter Laboratory of Parasitology. 174.

https://digitalcommons.unl.edu/parasitologyfacpubs/174

This Article is brought to you for free and open access by the Parasitology, Harold W. Manter Laboratory of at DigitalCommons@University of Nebraska - Lincoln. It has been accepted for inclusion in Faculty Publications from the Harold W. Manter Laboratory of Parasitology by an authorized administrator of DigitalCommons@University of Nebraska - Lincoln. 


\title{
THREE NEW COCCIDIA (APICOMPLEXA) FROM THE HOOD ISLAND LIZARD, TROPIDURUS DELANONIS, FROM THE GALÁPAGOS ARCHIPELAGO
}

\author{
Aida Luz Aquino-Shuster*, Donald W. Duszynski, and Howard L. Snell \\ Department of Biology, The University of New Mexico, Albuquerque, New Mexico 87131
}

ABSTRACT: Fecal samples of 14 Conolophus subcristatus from Isla Plaza Sur and of 24 Tropidurus delanonis from Isla Española and several satellite islets, Galápagos Islands, Ecuador, collected during June and July 1987 were examined for coccidian oocysts. None of the samples from $C$. subcristatus contained oocysts, but 11 of 24 (46\%) samples from $T$. delanonis had oocysts when examined. Two Eimeria and 1 Isospora spp. were present, which we describe here as new species. Sporulated oocysts of Eimeria tropidura n. sp. are ellipsoidal, $32.5 \times$ $23.8(21-38 \times 19-30) \mu \mathrm{m}$, with spheroidal to subspheroidal sporocysts, $8.2 \times 7.9(7-10 \times 5-10) \mu \mathrm{m}$. Sporulated oocysts of Eimeria galapagoensis $\mathrm{n}$. sp. are cylindroidal, $32.8 \times 14.0(27-36 \times 12-17) \mu \mathrm{m}$, with spheroidal sporocysts $7.5(7.5) \mu \mathrm{m}$. Sporulated oocysts of Isospora insularius $\mathrm{n}$. sp. are spheroidal to subspheroidal, 24.5 $\times 22.3(19-30 \times 18-27) \mu \mathrm{m}$, with lemon-shaped sporocysts, $16.6 \times 9.3(9-17 \times 7-13) \mu \mathrm{m}$. Each of the 11 positive fecal samples had oocysts of only 1 coccidian species, i.e., the different coccidian species did not share individual hosts.

During June and July 1987, we had the opportunity to collect fresh fecal samples from 2 species of Galápagos lizards, Conolophus subcristatus and Tropidurus delanonis. A number of the $T$. delanonis examined were passing coccidian oocysts that, upon closer study, represented 3 species, an isosporan and 2 eimerians that we describe here as new.

\section{MATERIALS AND METHODS}

During June 1987, we collected fresh fecal samples from 14 C. subcristatus from Isla Plaza Sur, and during July 1987, fresh samples were taken from $24 T$. delanonis from Isla Española (5), Isla Gardner por Española (8), Islote Osborn (7), and an unnamed islet (4) in Gardner Bay, the Galápagos Islands, Ecuador. All hosts were live-captured and fecal samples collected were placed in $2 \%(\mathrm{w} / \mathrm{v})$ aqueous potassium dichromate $\left(\mathrm{K}_{2} \mathrm{Cr}_{2} \mathrm{O}_{7}\right)$ and kept at ambient temperature. Once the samples were brought to Albuquerque in late July 1987 , we followed the procedures outlined by AquinoShuster and Duszynski (1989) for storing, processing, measuring, and photographing oocysts. All measurements are in $\mu \mathrm{m}$ with ranges in parentheses following the means.

As the Galápagos Islands constitute a national park, it was not possible to keep the hosts; thus, after collecting feces from hosts, each was released.

\section{RESULTS}

None of the fecal samples taken from $14 C$. subcristatus had oocysts in them. Of the samples

Received 10 October 1989; revised 27 December 1989; accepted 27 December 1989.

* Present address: Inventario Biologico Nacional, Museo de Historia Natural de Paraguay, Ministerio de Agricultura y Ganaderia, Sucursal 19, Ciudad Universitaria, San Lorenzo, Paraguay. taken from $T$. delanonis, 11 of 24 (46\%) had coccidian oocysts representing 3 species that we describe below as new. The different coccidian species did not share individual hosts, i.e., each of the 11 infected fecal samples had oocysts of only 1 coccidian species when examined.

\section{Eimeria tropidura n. sp.}

(Figs. 1-3, 10)

\section{Description}

Oocyst ellipsoidal, wall $\sim 2.0$, composed of 2 or 3 layers, that appear colorless under transmitted light; micropyle, oocyst residuum, and polar granule absent; sporulated oocysts $(n=54) 32.5 \times 23.8(21-38 \times 19$ $30)$ with $L: W$ ratio $1.4(1.0-1.6)$; sporocysts $(n=54)$ spheroidal to subspheroidal, $8.1 \times 7.9(7-10 \times 5-10)$ with L:W ratio 1.05 (1.0-1.5); Stieda, sub- and parastieda bodies absent; sporocyst residuum a compact mass $\sim 4.5-5.0$; sporozoites with a spheroidal posterior refractile body $\sim 2-3$.

\section{Taxonomic summary}

Type host: Tropidurus delanonis Baur, 1890 (Reptilia, Iguanidae).

Type locality: Islote Osborn, Galápagos, Ecuador.

Prevalence: Found in 9 of $24(38 \%) T$. delanonis including 6 of $7(86 \%)$ from Islote Osborn and 3 of 4 (75\%) from East Islet.

Site of infection: Unknown, oocysts collected from feces.

Material deposited: Syntypes (=phototypes, see Bandoni and Duszynski, 1988) of sporulated oocysts in the U.S. National Museum, Beltsville, Maryland, Parasite Collection (USNMPC) no. 80919.

Etymology: The nomen triviale is derived from the generic name of the host.

\section{Remarks}

Of the 53 eimerian species previously described from all lizards and geckos (see Discussion), sporulated 


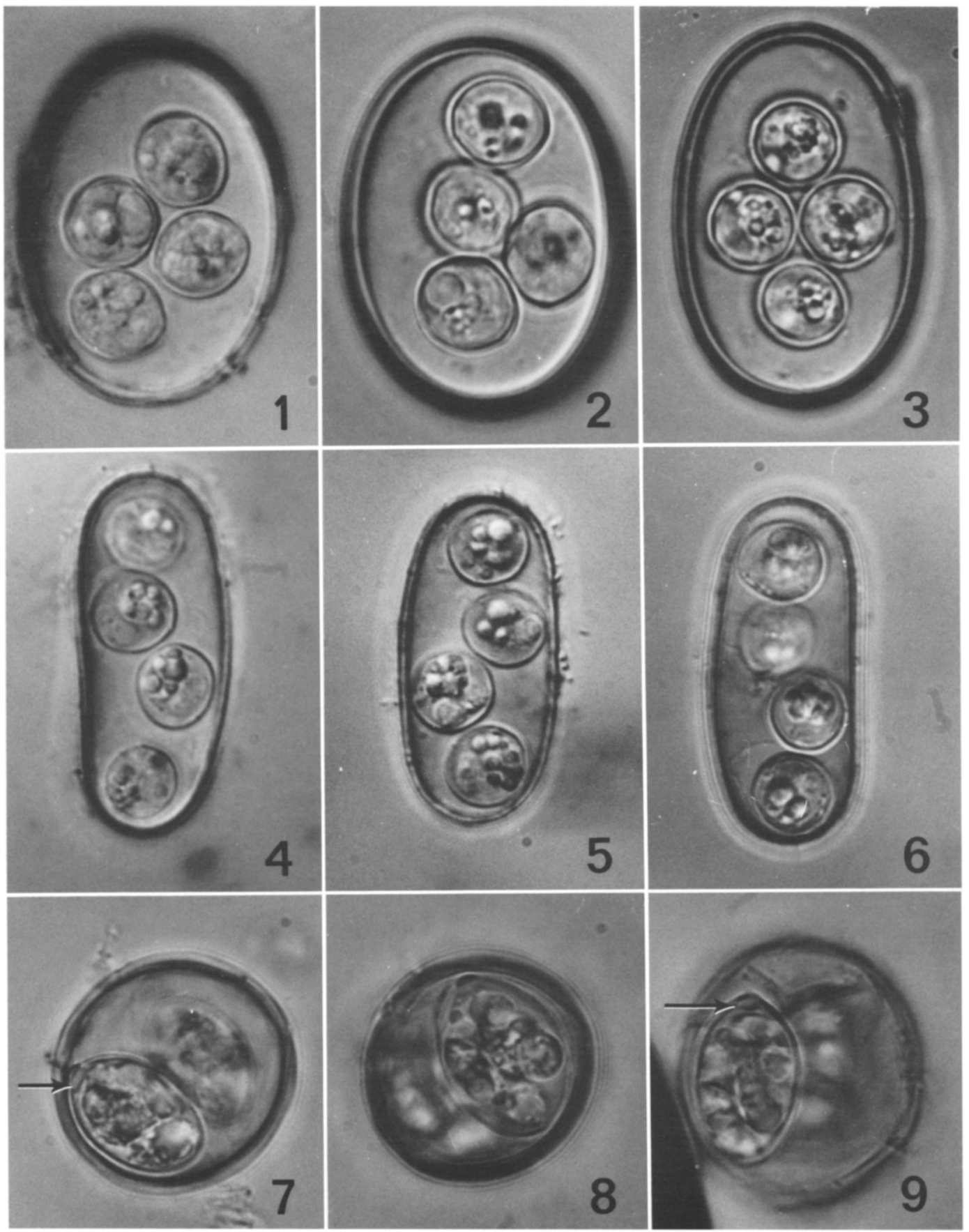

FIGURES 1-9. Photomicrographs of sporulated oocysts of coccidia collected from the feces of Tropidura delanonis. $\times 1,200$. 1-3. Eimeria tropidura $\mathrm{n}$. sp. Note multiple layers of oocyst wall, nearly spheroidal shape of sporocysts without Stieda or substieda bodies, and granular sporocyst residuum. 4-6. Eimeria galapagoensis sp. n. Note spheroidal shape of sporocysts without Stieda or substieda bodies and the sporocyst residuum of large refractile granules. 7-9. Isospora insularius $\mathrm{sp}$. $\mathrm{n}$. Note distinct Stieda body and substieda body (arrows). 
oocysts of $E$. tropidura are similar in size and/or shape to those of only 5 other species: Eimeria ahtanumensis Clark, 1970, from Sceloporus occidentalis from Washington, U.S.A.; Eimeria hispidi Bastardo de San Jose, 1974, from Tropidurus hispidus from Venezuela; $E i$ meria molochis Bovee and Telford, 1965, from Moloch horridus from Australia; Eimeria noctisauris Bovee and Telford, 1965, from Klauberina riversiana from California, U.S.A.; and Eimeria umis Bovee, 1969, from Uma notata from California, U.S.A. They differ from those of $E$. ahtanumensis by having oocysts with a smaller $\mathrm{L} / \mathrm{W}$ ratio (1.4 vs. 1.7 ) and $2-3$ obvious wall layers (vs. 1) that combined are thicker (2 vs. 1$)$ and by having nearly spheroidal $(8.1 \times 7.9)$ vs. ellipsoidal sporocysts $(11 \times 9)$. They differ from those of $E$. hispidi by being larger $(33 \times 24$ vs. $28 \times 26)$ with a larger L/W ratio (1.4 vs. 1.1$)$ and by having nearly spheroidal sporocysts vs. those that are ellipsoidal $(11 \times 9)$. They differ from those of $E$. molochis by having a thicker oocyst wall with 2-3 layers (vs. 1) and by having spheroidal (vs. ovoidal) sporocysts that are smaller with a different $\mathrm{L} / \mathrm{W}$ ratio (1.05 vs. 1.3). They differ from those of $E$. noctisauris by being smaller with a smaller $\mathrm{L} / \mathrm{W}$ ratio ( 1.4 vs. 1.7$)$ and a thicker wall ( 2.0 vs. 1.3$)$ and by having smaller sporocysts with a different $\mathrm{L} / \mathrm{W}$ ratio (1.05 vs. 1.4). Finally, they differ from those of E. umis by being less cylindroidal with a smaller $\mathrm{L} / \mathrm{W}$ ratio (1.4 vs. 1.9$)$ and a thicker wall ( 2 vs. 1$)$.

\section{Eimeria galapagoensis n. sp.} (Figs. 4-6, 11)

\section{Description}

Oocyst cylindroidal, wall $\sim 2.0$, with 2 colorless layers; micropyle, oocyst residuum, and polar granule absent; sporulated oocysts $(n=50) 32.8 \times 14.0(27-36$ $\times 12-17)$ with L:W ratio 2.4 (1.9-2.7); sporocysts (n $=50$ ) spheroidal, 7.5 , with $\mathrm{L}: \mathrm{W}$ ratio 1.0 ; Stieda, suband parastieda bodies absent; sporocyst residuum an irregular mass of highly refractile granules, $\sim 3.0$.

\section{Taxonomic summary}

Type host: Tropidurus delanonis Baur, 1890 (Reptilia, Iguanidae).

Type locality: Isla Gardner por Española, Galápagos, Ecuador.

Prevalence: Found in 1 of $8(12 \%) T$. delanonis from Isla Gardner por Española and 1 of $24(4 \%)$ of all $T$. delanonis sampled. feces.

Site of infection: Unknown, oocysts collected from

Material deposited: Syntypes (=phototypes) of sporulated oocysts, USNMPC no. 80920.

Etymology: The nomen triviale is derived from the name of the island group from which the hosts were collected and -ensis (L., belonging to).

\section{Remarks}

Only 8 eimerian species of the 53 described to date from lizards and geckos have sporulated oocysts with a L/W ratio greater than 2.0: Eimeria basilisci Duszynski, 1969 (2.1); Eimeria delalandii Matuschka and Bannert, 1986 (2.1); Eimeria japaluris Bovee, 1971 (2.3); Eimeria japonicus Bovee, 1971 (2.1); Eimeria koidzumii Matubayasi, 1941 (2.1); Eimeria pellopleuris Bovee, 1971 (2.2); Eimeria subcylindrica Arcay-de-
Peraza and Bastardo de San Jose, 1970 (2.2); and Eimeria turcicus Upton, McAllister, and Freed, 1988 (2.1). However, only E. subcylindrica, found in the gall bladder of Ameiva ameiva from Venezuela (Arcay-de-Peraza and Bastardo de San Jose, 1970), has spheroidal sporocysts. Eimeria galapagoensis differs from $E$. subcylindrica by being considerably smaller $(33 \times 14$ vs. $41 \times 19)$ and having smaller sporocysts (7.5 vs. 10.8$)$.

Isospora insularius n. sp. (Figs. 7-9, 12)

\section{Description}

Oocyst spheroidal to subspheroidal, wall 2.0 , composed of 2 colorless layers; micropyle and oocyst residuum are absent, but highly refractile polar body is present; sporulated oocysts $(n=50) 24.5 \times 22.3(19$ $30 \times 18-27)$ with $\mathrm{L}: \mathrm{W}$ ratio $1.1(1.0-1.3)$; sporocysts $(\mathrm{n}=50)$ ovoidal (lemon-shaped), $12.6 \times 9.3(9-17 \times$ 7-13), with L:W ratio 1.3 (1.1-1.8); Stieda and substieda bodies present with substieda body $2 \times$ wider than Stieda body, but parastieda body absent; sporocyst residuum a compact mass, $\sim 5.3$.

\section{Taxonomic summary}

Type host: Tropidurus delanonis Baur, 1890 (Reptilia, Iguanidae).

Type locality: Isla Española, Galápagos, Ecuador.

Prevalence: Found in 1 of $5(20 \%) T$. delanonis from Isla Española and 1 of $24(4 \%)$ of all $T$. delanonis sampled.

Site of infection: Unknown, oocysts collected from feces.

Material deposited: Syntypes (=phototypes) of sporulated oocysts, USNMPC no. 80921.

Etymology: The nomen triviale combines insula(L., an island) and -arius (L., denotes belonging to), emphasizing the habitat of the host.

\section{Remarks}

Looking at the 32 named and unnamed isosporan species described from all saurian hosts worldwide (see Discussion) we are struck by the remarkable similarity between sporulated oocysts of many of the species, especially when only oocyst and sporocyst shapes and length/width dimensions are considered. For example, oocysts and sporocysts of $I$. insularius resemble those of at least 12 other described species in general size and shape: Isospora ablephari Cannon, 1967; Isospora amphiboluri Cannon, 1967; Isospora caryophila Rogier and Colley, 1976; Isospora gymnodactyli Ovezmukhammedov, 1972; Isospora hemidactyli Carini, 1936; Isospora manchacensis Atkinson and Ayala, 1987; Isospora phrynocephali Ovezmukhammedov, 1971; Isospora sp. Cannon, 1967; Isospora tarentolae Matuschka and Bannert, 1986; Isospora thavari Else and Colley, 1975; Isospora varani Yakimoff, 1938; and Isospora viridanae Matuschka, 1989.

Only by looking at the original papers describing these 12 species can we confidently eliminate 5 of them (I. gymnodactyli, I. hemidactyli, I. pharynocephali, I. thavari, I. varani) because they all have sporocysts that lack a substieda body and most have other qualitative features (e.g., consistent absence of a polar body) or quantitative differences (e.g., a thin, single-layered 

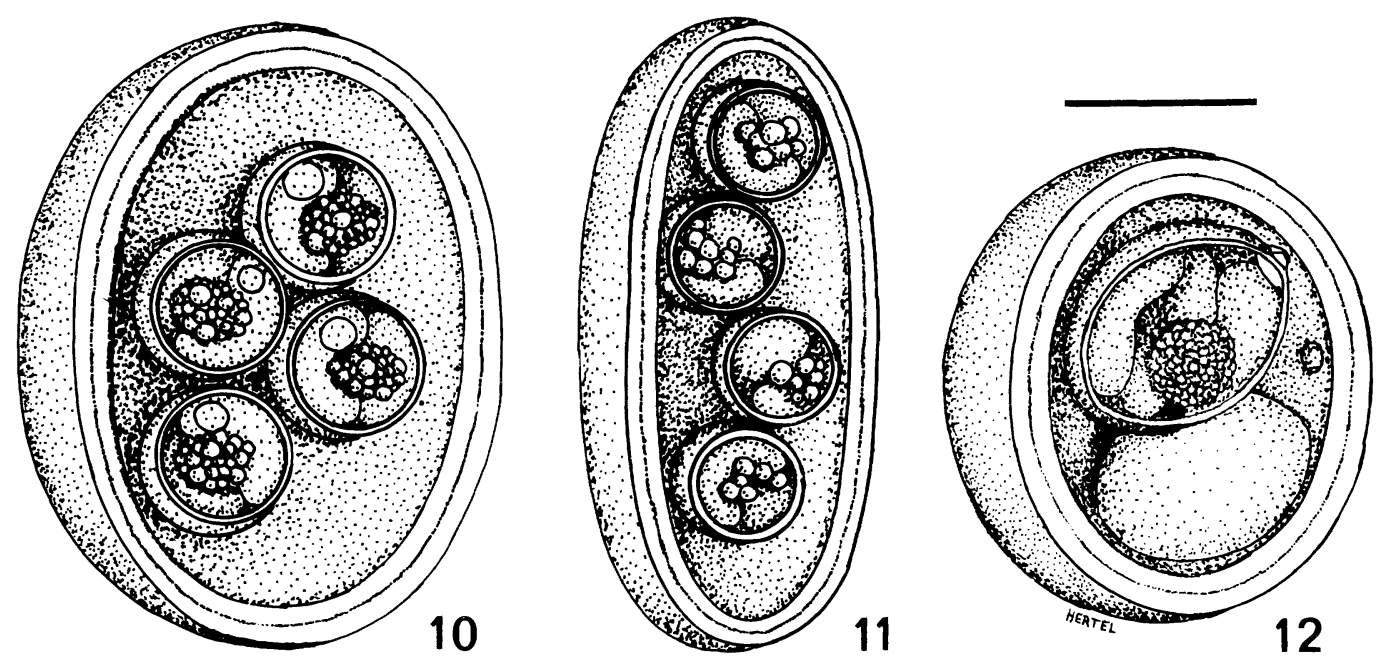

FIGURES 10-12. Line drawings of sporulated oocysts of coccidia collected from feces of Tropidura delanonis. $\mathrm{Bar}=10 \mu \mathrm{m}$. 10. Eimeria tropidura. 11. Eimeria galapagoensis. 12. Isospora insularius.

oocyst wall). Separating oocysts of $I$. insularius from the other 7 species noted above is not so easy.

Both I. ablephari and I. amphiboluri described, respectively, from Ablepharus boutonii and Amphibolurus barbatus in Australia by Cannon (1967), have sporocysts with a thickening at the pointed end (presumably a Stieda body) "surmounting a large refractile globule." We interpret this latter structure to be a substieda body, but it is not possible to conclude from his illustration that this is what he meant. Both species also lack polar bodies. Otherwise, the oocyst wall structure, size and shape of the oocysts and sporocysts, and presence or absence of structures such as residua are identical to those of $I$. insularius oocysts. Only the hosts and continents on which the hosts are found are different.

Oocysts and sporocysts of I. caryophila described from Gonyocephala grandis from Kuala Lumpur, Malaysia (Rogier and Colley, 1976) are identical in size and shape to those of $I$. insularius. Although a substieda body is not mentioned in the description, the drawing by Rogier and Colley (1976) shows that one is present, as is a polar body; unfortunately, there is no published photomicrograph to confirm their drawing. The only structural difference is that the oocyst wall of $I$. caryophila is described as simple (the drawing shows only 1 layer), yellowish, and 0.6 "thick."

Oocysts of $I$. manchacensis from the Louisiana ground skink, Scincella lateralis, are identical to those of $I$. insularius, except that they appear to have only 1 oocyst wall layer and they lack a polar body (Atkinson and Ayala, 1987).

Cannon (1967) also measured a few oocysts from Phyllurus cornutus, a rain forest gecko from Queensland, Australia, and said they were similar to those of I. ablephari (and, therefore, similar to those of $I$. insularius), but he did not name or describe these oocysts further.

Measurements, photomicrographs, and all qualitative features of I. tarentolae oocysts described from the gecko Tarentola delalandis from Tenerife in the Canary Islands (Matuschka and Bannert, 1986a) are identical to those of $I$. insularius except that $I$. tarentolae oocysts are described as lacking a polar body and having a bilayered oocyst wall $\sim 1.0$, whereas the oocyst wall of I. insularius is bilayered, but clearly thicker, $\sim 2.0$.

Finally, oocysts of $I$. viridanae, recently described from the skink, Chalcides viridanus, also from Tenerife (Matuschka, 1989), are spheroidal, 22 (18-32), and lack a polar body, but otherwise they are indistinguishable from those of $I$. insularius. Although Matuschka (1989) did not state the thickness of the oocyst wall or its number of layers, his photomicrographs show an oocyst wall identical to that of $I$. insularius.

Given that we know of no isosporan or eimerian from lizards that has ever been shown to cross generic boundaries (although no one has tested this), let alone continents, we name the isosporan described here from $T$. delanonis as a new species.

\section{DISCUSSION}

As best we can determine, there are about 53 named eimerian species described from saurians including 14 listed by Matuschka and Bannert (1986b), 30 by Matuschka and Bannert (1987), and 1 each by Arcay-de-Peraza and Bastardo de San Jose (1970), Bastardo de San Jose (1974), Borst et al. (1975), Levine (1988), Matuschka and Bannert (1986a), Upton and Barnard (1987), McAllister et al. (1988, 1990), and Upton et al. (1988). In addition, there are also 32 named and 3 unnamed isosporan species described, to date, from lizards (Upton et al., 1988; Amoudi, 1989; Matuschka, 1989). Of interest in this study and to others who will examine lizards for coccidians 
is that the eimerians from these hosts produce oocysts that are quite distinctive structurally, whereas sporulated oocysts of many isosporans described from unrelated host species worldwide are virtually indistinguishable.

The strong similarity of these sporulated isosporan oocysts creates a nightmare for taxonomists, especially because no phototypes of oocysts are available for comparative purposes (see Bandoni and Duszynski, 1988). On the other hand, the patterns of oocyst structure seen, highly distinctive eimerian oocysts vs. highly similar isosporan oocysts, may present an interesting comparison about the relative rates of evolution of oocyst structure in these 2 genera of common lizard parasites. It would seem that oocyst structure may be evolving more rapidly in eimerians than in isosporans found in lizards. In both, however, the evolution of structural traits may be considered conservative when compared to the evolution of host specificity (see Barker et al., 1989).

The fact that coccidians are relatively prevalent in $T$. delanonis (46\%), but are absent from C. subcristatus in the same archipelago, needs further study. Although these 2 host species are never sympatric in the Galápagos, other Tropidurus species do occur with $C$. subcristatus; unfortunately, there are no data available on the coccidian parasites of these other species.

It may be possible to compare some gross aspects of the physiological ecology of Conolophus and Tropidurus to help explain their differences in susceptibility, but the data that are available are not informative. The body temperatures of the 2 lizard species are apparently equal (Stebbins et al., 1967; Werner, 1977; Snell and Christian, 1985; Snell et al., 1988). Therefore, the thermal environment provided by these potential hosts to coccidians is not different enough to explain their apparent variations in susceptibility.

The 2 lizard species differ somewhat in diet, with $C$. subcristatus being almost exclusively herbivorous (Snell and Tracy, 1985), whereas the level of herbivory in $T$. delanonis depends upon size (and age), with juveniles being less herbivorous than large adults (Werner, 1977; Schluter, 1984). Contaminated vegetation can be imagined to play an important role in the transmission of coccidian oocysts, but given the known dietary patterns of the 2 species, it might be predicted that $C$. subcristatus should be more likely to harbor coccidians, which we did not find to be the case.

One important difference between these species of lizards that may contribute to the infection patterns seen is their respective population densities. Tropidurus delanonis on Isla Española average 154.8 individuals per hectare (Werner, 1977), whereas C. subcristatus on Isla Plaza Sur average only 55.4 per hectare (Snell and Christian, 1985). The greater density of $T$. delanonis certainly could contribute to the maintenance of a higher infection rate for parasites with 1-host life cycles.

\section{ACKNOWLEDGMENTS}

Sincere thanks to Dr. Steve Upton, Kansas State University, for the generous use of his reprint library that allowed us to complete this study in a timely fashion and for his helpful suggestions in reading the manuscript. We also thank Lynn Hertel for the line drawings and (former) Dean Marcus Price, Office of Graduate Studies, The University of New Mexico (UNM), the Fulbright Research Scholar Program, and the Latin American Institute of UNM for financial support for the work. We are sincerely indebted to the Charles Darwin Research Station and the Galápagos National Park Service for logistical help and for permission to work in the Galápagos National Park.

\section{LITERATURE CITED}

Amoudi, M. A. 1989. Two new species of Isospora from the desert skink (Chalchides ocellatus) from the Egyptian desert. Journal of Protozoology 36: 237-238.

AQuino-SHuster, A. L., AND D. W. DUSZYNSKI. 1989. Coccidian parasites (Apicomplexa: Eimeriidae) from two species of caimans, Caiman yacare Daudin and Caiman latirostris Daudin (Alligatoridae) from Paraguay. Journal of Parasitology 75: 348352.

Arcay-de-Peraza, L., AND T. Bastardo de San Jose. 1970. Nuevos coccidia de lagartos: Wenyonella ameivae sp. nov. y Eimeria subcylindrica sp. nov. (Coccidia, Eimeriidae), parasitos de Ameiva ameiva de Venezuela. Acta IV Congreso Latinoamericano de Zoologia 1: 265-275.

Atkinson, C. T., AND S. C. AyAlA. 1987. Isospora manchacensis $\mathrm{n}$. sp., an intranuclear coccidian from the Louisiana ground skink, Scincella lateralis (Say, 1823) (Lacertilia: Scincidae). Journal of Parasitology 73: 817-823.

BANDONI, S. M., AND D. W. DuszYNSKI. 1988. A plea for improved presentation of type material for coccidia. Journal of Parasitology 74: 519-523.

BARKer, I. K., M. G. O'CAllaghan, AND I. BEVERIDGe. 
1989. Host-parasite associations of Eimeria spp. (Apicomplexa: Eimeriidae) in kangaroos and wallabies of the genus Macropus (Marsupialia: Macropodidae). International Journal for Parasitology 19: 241-263.

Bastardo de San Jose, T. 1974. Descripcion y ciclo evolutivo de dos nuevos coccidia de Tropidurus hispidus de Venezuela: Wenyonella arcayae $\mathrm{sp} . \mathrm{n}$. y Eimeria hispidi $\mathbf{s p}$. n. con discusion de la clasificacion de los Eimeriidae y nueva diagnosis para el genero Wenyonella Hoare, 1933. Acta Biologia Venezuela 8: 567-578.

Borst, G. H. A., M.-L. Peters, and W. Weijerman. 1975. Eimeria polydaedali $\mathrm{sp}$. n. from the Nile monitor, Varanus niloticus. Zeitschrift für Parasitenkunde 47: 187-189.

Cannon, L. R. G. 1967. New coccidia from Australian lizards. I. Isospora. Parasitology 57: 227-235.

LEVINE, N. D. 1988. The protozoan phylum Apicomplexa, Vol. I. CRC Press, Inc., Boca Raton, Florida, $203 \mathrm{p}$.

MATUSChKA, F.-R. 1989. Isospora viridanae n. sp., an intranuclear coccidian parasite from the Canarian skink, Chalcides viridanus (Lacertilia: Scincidae). Journal of Protozoology 36: 274-279.

, AND B. BANNERT. 1986a. Eimeria tarentolae n. sp. from the Moorish Gecko, Tarentola mauritanica. Journal of Protozoology 33: 309-31 1. , AND - 1986b. New eimeriid coccidia from the gecko Tarentola delalandii Dumeril \& Bibron, 1836. Prostitologica 4: 399-403.

— , AND —. 1987. New eimeriid coccidia from the Canarian lizard, Gallotia galloti Oudart, 1839. Journal of Protozoology 34: 231-235.

MCAllister, C. T., S. J. Upton, AND P. S. Freed. 1988. Eimeria lineri sp. n. (Apicomplexa: Eimeriidae) from the Mediterranean gecko, Hemidactylus trucicus (Sauria: Gekkonidae), in Louisiana and Texas. Proceedings of the Helminthological Society of Washington 58: 256259. $\longrightarrow,-$ AND D. M. BOYER. 1990. Eimeria dixoni sp. n. (Apicomplexa: Eimeriidae) from an introduced population of common house geckos, Hemidactylus frenatus (Sauria: Gekkonidae), in Dallas County, Texas. Journal of the Helminthological Society of Washington 57: 1-4.

Rogier, E., AND F. Colley. 1976. Description d'Isospora caryophila $\mathrm{n}$. sp. parasite d'un agamide' de Malaisie péninsulaire. Protistologica 12: 369-373.

SCHLUTER, D. 1984. Body size, prey size and herbivory in the Galapagos lava lizard, Tropidurus. Oikos 43: 291-300.

Snell, H. L., AND K. A. Christian. 1985. Energetics of Galapagos land iguanas: A comparison of two island populations. Herpetologica 41: 437-442.

$\longrightarrow$, R. D. JenNings, H. M. SNELl, AND S. A. HARCOURT. 1988. Intrapopulation variation in predator avoidance performance of Galapagos lava lizards: The interaction of sexual and natural selection. Evolutionary Ecology 2: 353-369.

, AND C. R. TRACY. 1985. Behavioral and morphological adaptations by Galapagos land iguanas (Conolophus subcristatus) to water and energy requirements of eggs and neonates. American Zoologist 25: 1009-1018.

Stebins, R. C., J. M. Lowenstein, AND N. W. Cohen. 1967. A field study of the lava lizard (Tropidurus albemarlensis) in the Galapagos islands. Ecology 48: 839-851.

Upton, S. J., AND S. M. Barnard. 1987. Two new species of coccidia (Apicomplexa: Eimeriidae) from Madagascar gekkonids. Journal of Protozoology 34: 452-454.

, C. T. McAllister, AND P. S. Freed. 1988 Eimeria turcicus n. sp. (Apicomplexa: Eimeriidae) from the Mediterranean gecko, Hemidactylus turcicus (Sauria: Gekkonidae). Journal of Protozoology 35: 24-25.

WERnER, D. I. 1977. On the biology of Tropidurus delanonis Baur (Iguanidae). Zeitschrift für Tierpsychologie 47: 337-395. 